\title{
Admission Hyperglycemia in Non-diabetics Predicts Mortality and Disease Severity in COVID-19: a Pooled Analysis and Meta-summary of Literature
}

\author{
Sonali Sachdeva ${ }^{1} \cdot$ Rupak Desai $^{2}$ (D) Udita Gupta ${ }^{3} \cdot$ Anupam Prakash $^{3} \cdot$ Abhinav Jain $^{4} \cdot$ Ankita Aggarwal $^{5}$
}

Accepted: 4 October 2020 / Published online: 12 October 2020

(C) Springer Nature Switzerland AG 2020

\begin{abstract}
In the latter part of 2019, a cluster of unexplained pneumonia cases were reported in Wuhan, China. In less than a year, SARSCoV-2 has infected over 27 million people and claimed more than 800,000 deaths worldwide. Diabetes is a highly prevalent chronic metabolic disease, and recent reports have suggested a possible existence of COVID-19 related new-onset diabetes. Hyperglycemia induces an inflammatory state in the body, which coupled with coronavirus associated immune response is a possible explanation for clinical worsening of patients. We present a summary and pooled analysis of available evidence to ascertain the relationship between hyperglycemia in undiagnosed diabetics and outcomes of COVID-19 disease. Our results showed that hyperglycemia in non-diabetics was associated with higher risk of severe/critical illness (OR 1.837 (95\% CI 1.368$2.465, P<0.001)$ and mortality $(2.822,95 \%$ CI $1.587-5.019, P<0.001)$ compared with those with normal values of blood glucose. The management of hyperglycemia in COVID-19 poses significant challenges in clinical practice, and the need to develop strategies for optimal glucose control in these patients cannot be overlooked.
\end{abstract}

Keywords COVID-19 $\cdot$ SARS-CoV-2 $\cdot$ Hyperglycemia $\cdot$ Diabetes $\cdot$ Infectious disease

\section{Introduction}

The first case of novel coronavirus pneumonia, also known as SARS-CoV-2 (severe acute respiratory distress syndrome coronavirus-2), emerged in December 2019 in Wuhan, China. Designated as coronavirus disease 2019 (COVID-19), it affects the lungs primarily and has a high transmission rate [1].

This article is part of the Topical Collection on Covid-19

Rupak Desai

rdesa30@emory.edu; drrupakdesai@gmail.com

1 Department of Anesthesiology and Critical Care Medicine, Maulana Azad Medical College, New Delhi, India

2 Division of Cardiology, Atlanta VA Medical Center, 1670 Clairmont Rd, Decatur, GA, USA

3 Division of General Medicine, Lady Hardinge Medical College, New Delhi, India

4 Department of Cardiology, Ascension Genesys Hospital, Grand Blanc, MI, USA

5 Department of Internal Medicine, Wayne State University, Detroit, MI, USA
Diabetes as a risk factor for severe COVID-19 disease has already been studied and reported in detail [2]. SARS-CoV2 interacts with the body's glucose metabolism via a variety of pathways, the commonest being ACE-2 expression in the pancreas [3]. It is well established that hyperglycemia increases the risk of lower respiratory tract infections and is linked to poor outcomes [4]. Since an acute rise in blood glucose is associated with increased inflammatory mediators [5], it is conceivable that hyperglycemia can potentiate the harmful effects of cytokine storm in patients with COVID-19 pneumonia. Hence, there is growing concern that hyperglycemia independent of diabetes could be a factor contributing to poor prognosis in COVID-19 illness. This study aims to shed light on the correlation between hyperglycemia in those without an established diagnosis of diabetes mellitus and COVID-19related clinical outcomes.

\section{Methods}

A literature search was performed in August and September 2020 using databases PubMed, Google scholar, and Scopus to identify studies reporting an association between blood 
glucose levels and COVID-19 disease outcomes in patients without a history of diabetes. The search strategy consisted of different combinations of the following keywords: "COVID-19," "SARS-CoV-2," "hyperglycemia," "impaired glucose tolerance," "prediabetes," and "impaired fasting glucose." Those with raised blood glucose, no prior history of diabetes, and those with prediabetes and impaired fasting glucose were placed Group 1 designated as "hyperglycemia without diabetes." On the other hand, patients found to have normal blood glucose values on admission were part of the normoglycemia group (Group 2); refer to Table 1. The presence of diabetes was negated by one of the following: a negative history of diabetes as per the patient or his/her medical records, lack of ongoing treatment with glucose-lowering medications, or HBAIc $<6.5$. The criteria for inclusion into these two groups for each study have been mentioned in Table 1. Whenever available, data on the following was included: clinical features, in-hospital complications, patient outcomes such as mechanical ventilation and ICU admission, disease severity and mortality among laboratory-confirmed, and SARS-CoV-2 patients in the hyperglycemia and normoglycemia groups. We excluded duplicate studies, letters, case reports, abstracts, reviews, and articles not translated in English.

Statistical analysis was performed using OpenMeta[Analyst ] software. Odds ratio (OR) with $95 \%$ confidence interval (CI) was determined and pooled analysis performed to determine the pooled odds ratio. Heterogeneity was assessed using the $I^{2}$ test, and $I^{2}>50 \%$ was considered as a moderate inter-study variation. A $P<0.05$ was considered statistically significant.

\section{Results}

Initial search yielded 423 studies. After excluding irrelevant articles, reviews, and duplicate items, a total of 13 studies were included. Ten studies were included in quantitative analysis (pooled OR for severe/critical COVID-19 and death). These ten studies have been summarized in Table 1 .

\section{Clinical Features and Demographics}

Studies have shown that COVID-19 patients with hyperglycemia are older compared with those with normal blood glucose levels. A retrospective study by Zhang et al. included data of 312 COVID-19 patients and stratified them according to diabetic status into the following three groups-diabetes, impaired fasting glucose (IFG), and normal fasting glucose (NFG). Those who were diagnosed as having an impaired fasting glucose were older than those with normal fasting glucose (mean age 62 years vs 46 years, $P<0.001$ ) and had a higher burden of comorbidities $(45 \%$ vs $25 \%, P<0.001)$. Men comprised a larger proportion of COVID-19 patients presenting with impaired fasting glucose, compared with those without hyperglycemia (55\% vs $34 \%$ ). Further, they also reported data on common coronavirus disease symptoms. Dyspnea (55\% vs $33 \%$ ) and hypoxemia (48\% vs $24 \%$ ) were more commonly seen in the IFG cohort compared with the normal fasting glucose group $(P<0.001)$. Fever $(92 \%$ vs $82 \%$ ), chest pain ( $42 \%$ vs $40 \%$ ), diarrhea ( $27 \%$ vs $20 \%$ ), nausea and vomiting ( $15 \%$ vs $11 \%)$, and polypnea ( $13 \%$ vs $5 \%$ ) were also seen with a greater frequency in among those with IFG, compared with those with NFG, although the difference was not statistically significant $(P>0.05)[6]$.

\section{Lab Markers and Imaging}

Compared with patients with normal glucose levels, those with hyperglycemia had more abnormalities in lab markers. Zhang et al. reported various irregularities in laboratory values of COVID-19 patients who were also concurrently diagnosed as having raised blood glucose. Increased neutrophils and leukocytes, decreased eosinophils, were more commonly seen in those with hyperglycemia compared with known diabetics and those with normal blood glucose levels. Abnormalities in liver function test components such as hypoalbuminemia and raised ALT levels were also more commonly recognized in patients belonging to the hyperglycemia group vs the normoglycemia and diabetic group. Similar trend was observed in case of inflammatory markers such as lactate dehydrogenase (LDH), ferritin, and C-reactive protein (CRP). Interestingly, IL-8, an important component of inflammatory response, was also significantly higher in this group compared with the other two $(23.8 \%$ vs $4.8 \%, P<0.05)$ [7].

Disturbed coagulation profile is an important prognostic finding in COVID-19 patients. Significantly raised D-Dimer (27\% vs $17 \%)$ and fibrinogen levels (68\% vs $37 \%)$ were observed in those with impaired fasting glucose compared with ones with a normal fasting glucose in the retrospective observational study by Zhang et al. [6]. They also reported higher Troponin 1, AST, ALT, cystatin C, neutrophil/lymphocyte $(\mathrm{N} / \mathrm{L})$ ratios, and decreased lymphocytes and platelets in the same subset of patients, compared with those with normal glucose tolerance $(P<0.05)$.

Aggravated findings on CT scan imaging of the chest were more frequently observed in those with impaired fasting glucose compared with COVID-19 patients with normal fasting glucose [6]. Lacobellis et al. reported that admission hyperglycemia (day-1 average blood glucose levels) was the strongest predictor of radiographic findings of SARS-CoV2 pneumonia in patients without a known history of diabetes, even after accounting for body temperature [16]. It would not be wrong to believe that heightened inflammation and exacerbated immune response, as a result of acute hyperglycemia, could be responsible for radiographic progression of ARDS in these patients. 
Table 1 Summary of studies included in quantitative analysis (pooled OR for severe/critical COVID-19 illness and mortality)

\begin{tabular}{|c|c|c|c|c|}
\hline Author & Type of study & Region & Patients included & $\begin{array}{l}\text { Criteria for classification into } \\
\text { Group } 1 \text { and Group } 2\end{array}$ \\
\hline $\begin{array}{l}\text { Zhang } \\
\text { et al. } \\
\text { [6] }\end{array}$ & $\begin{array}{l}\text { Multicenter } \\
\text { retrospec- } \\
\text { tive cohort } \\
\text { study }\end{array}$ & China & $\begin{array}{l}312 \text { hospitalized patients with } \\
\text { COVID-19; status of diabetes } \\
\text { and hyperglycemia } \\
\text { ascertained at admission }\end{array}$ & $\begin{array}{l}\text { Based on Group1-Normal } \\
\text { fasting glucose (NFG)- } \\
<5.6 \mathrm{mmol} / \mathrm{L} \text { and Group } 2- \\
\text { impaired fasting glucose } \\
\text { (IFG) }-5.6-6.9 \mathrm{mmol} / \mathrm{L}\end{array}$ \\
\hline $\begin{array}{l}\text { Zhang } \\
\text { et al. } \\
\text { [7] }\end{array}$ & $\begin{array}{l}\text { Single-center } \\
\text { retrospec- } \\
\text { tive cohort } \\
\text { study }\end{array}$ & China & $\begin{array}{l}166 \text { hospitalized COVID-19 pa- } \\
\text { tients with blood glucose } \\
\text { measurement at admission }\end{array}$ & $\begin{array}{l}\text { Group } 1-\text { Fasting plasma glu- } \\
\text { cose }(\mathrm{FPG})<7.0 \mathrm{mmol} / \mathrm{L} \text { and } \\
\text { no history of diabetes, Group } \\
2-\mathrm{FPG} \geq 7.0 \mathrm{mmol} / \mathrm{L} \text { once } \\
\text { and } \mathrm{HBA} 1 \mathrm{c}<6.5\end{array}$ \\
\hline $\begin{array}{l}\text { Fadini } \\
\text { et al. } \\
\text { [8] }\end{array}$ & $\begin{array}{l}\text { Retrospective } \\
\text { observa- } \\
\text { tional study }\end{array}$ & Italy & $\begin{array}{l}413 \text { COVID-19 patients; fasting } \\
\text { plasma glucose measured at } \\
\text { admission }\end{array}$ & $\begin{array}{l}\text { Diabetes was defined as } \\
\text { HBA1c }<6.5 \text { or random blood } \\
\text { glucose }>200 \mathrm{mg} / \mathrm{dL} \text { or based } \\
\text { on patient's electronic medical } \\
\text { records, medication history, } \\
\text { and self- reporting; reported } \\
\text { odds ratio in non-diabetics. }\end{array}$ \\
\hline $\begin{array}{c}\text { Liu et al. } \\
\text { [9] }\end{array}$ & $\begin{array}{l}\text { Multicenter } \\
\text { retrospec- } \\
\text { tive cohort } \\
\text { study }\end{array}$ & China & $\begin{array}{l}123 \text { COVID-19 patients; glucose } \\
\text { measurement at hospital ad- } \\
\text { mission }\end{array}$ & $\begin{array}{l}\text { Ruled out diabetes with negative } \\
\text { history and adjusted for } \\
\text { diabetes in the calculation of } \\
\text { odds ratio. }\end{array}$ \\
\hline $\begin{array}{l}\text { Coppelli } \\
\text { et al. } \\
{[10]}\end{array}$ & $\begin{array}{l}\text { Retrospective } \\
\text { observa- } \\
\text { tional study }\end{array}$ & Italy & $\begin{array}{l}271 \text { hospitalized COVID-19 pa- } \\
\text { tients; at admission glycemia } \\
\text { status }\end{array}$ & $\begin{array}{l}\text { Group 1: Normoglycemia- } \\
\text { glucose level }<7.78 \mathrm{mmol} / \mathrm{L} ; \\
\text { Group 2: glucose } \\
\text { level }<7.78 \mathrm{mmol} / \mathrm{L} \text { and no } \\
\text { previous history of diabetes } \\
\text { mellitus. }\end{array}$ \\
\hline $\begin{array}{l}\text { Wang } \\
\text { et al. } \\
{[11]}\end{array}$ & $\begin{array}{l}\text { Multicenter } \\
\text { retrospec- } \\
\text { tive cohort } \\
\text { study }\end{array}$ & China & $\begin{array}{l}605 \text { COVID-19 hospitalized pa- } \\
\text { tients without a previous di- } \\
\text { agnosis of diabetes; fasting } \\
\text { plasma glucose (FPG) was } \\
\text { measured at admission }\end{array}$ & $\begin{array}{l}\text { Group 1: } \mathrm{FPG}<6.1 \mathrm{mmol} / \mathrm{L} \text {; } \\
\text { Group 2: FPG } \\
\text { 6.1-6.9 mmol/L }\end{array}$ \\
\hline $\begin{array}{l}\text { Li et al. } \\
\text { [12] }\end{array}$ & $\begin{array}{l}\text { Single-center } \\
\text { retrospec- } \\
\text { tive cohort } \\
\text { study }\end{array}$ & China & $\begin{array}{l}453 \text { hospitalized COVID-19 pa- } \\
\text { tients; blood glucose measured } \\
\text { at admission }\end{array}$ & $\begin{array}{l}\text { Group 1-normal glucose; } \\
\text { Group 2-hyperglycemia - } \\
\text { 5.6-6.9 mmol/L }\end{array}$ \\
\hline $\begin{array}{l}\text { Wu et al. } \\
\text { [13] }\end{array}$ & $\begin{array}{l}\text { Multicenter } \\
\text { retrospec- } \\
\text { tive cohort } \\
\text { study }\end{array}$ & China & $\begin{array}{l}2041 \text { hospitalized COVID-19 } \\
\text { patients; median blood glu- } \\
\text { cose in hospital }\end{array}$ & $\begin{array}{l}\text { Group 1: median glucose } \\
<6.1 \mathrm{mmol} / \mathrm{L}, \text { Group } 2 \text { : blood } \\
\text { glucose } \geq 6.1 \mathrm{mmol} / \mathrm{L} \text { after } \\
\text { admission }\end{array}$ \\
\hline $\begin{array}{l}\text { Bode at } \\
\text { al [14] }\end{array}$ & $\begin{array}{l}\text { Retrospective } \\
\text { observa- } \\
\text { tional study }\end{array}$ & USA & $\begin{array}{l}1122 \text { hospitalized COVID-19 } \\
\text { patients included in the } \\
\text { GLYTEC database. }\end{array}$ & $\begin{array}{l}\text { Group 1: uncontrolled } \\
\text { hyperglycemia - two blood } \\
\text { glucose measurements } \\
>180 \mathrm{mg} / \mathrm{dL} \text { within any } 24-\mathrm{h} \\
\text { periods and HBA1c }<6.5 \% \text {; } \\
\text { Group 2: patients who did not } \\
\text { meet the criteria for inclusion } \\
\text { into Group } 1\end{array}$ \\
\hline $\begin{array}{l}\text { Smith } \\
\text { et al. } \\
{[15]}\end{array}$ & $\begin{array}{l}\text { Retrospective } \\
\text { observa- } \\
\text { tional study }\end{array}$ & USA & $\begin{array}{l}184 \text { hospitalized COVID-19 pa- } \\
\text { tients; diabetic status } \\
\text { ascertained at admission }\end{array}$ & $\begin{array}{l}\text { Group 1: Non-DM_-fasting } \\
\text { blood } \leq 125 \mathrm{mg} / \mathrm{dL} \\
(6.9 \mathrm{mmol} / \mathrm{L}) \text { and HBA1c } \\
<5.7 \text {; Group 2: Pre } \\
\text { DM-HBA1c 5.7-6.4 }\end{array}$ \\
\hline
\end{tabular}

\section{Disease Severity and Complications}

Sardu et al. in a study assessing the role of insulin in controlling blood sugar levels among COVID-19 patients also compared the risk of severe disease in patients with diabetes, hyperglycemia without diabetes, and normoglycemia. After risk-adjusted Cox regression analysis, they found that patients with hyperglycemia had an increased risk of severe COVID-19 disease [17]. 
Six studies reported quantitative data on severe/critical COVID-19 illness. Critical illness/severe disease was defined by the occurrence of adverse clinical outcomes such as respiratory failure requiring mechanical ventilation, ICU admission for organ failure, in-hospital complications, shock, or death. Some Chinese studies defined disease severity as per Chinese COVID-19 management guidelines or COVID-19 guidelines issued by Chinese National Health Committee. One study defined severe COVID-19 using the Infectious Disease Society of America/American thoracic society CAP severity criteria. Pooled odds ratio was calculated using a random effects model. Pooled OR for severe/critical COVID-19 illness among patients with hyperglycemia was 1.837 (95\% CI 1.368-2.465, $P<0.001$ ) (Fig. 1a). Other studies reported separately the clinical outcomes that comprise critical/severe COVID-19 illness, as shown in Table 2.

Recent evidence suggests that every $2 \mathrm{mmol} / \mathrm{L}(36 \mathrm{mg} / \mathrm{dL}$ ) increase in fasting plasma glucose levels correlates with increasing COVID-19 severity in both diabetics and non-diabetics, but the association was stronger among the latter [8]. Furthermore, the optimal fasting blood glucose levels for predicting critical COVID-19 illness were reported to be $\geq$ $6.50 \mathrm{mmol} / \mathrm{L}$ [9]. $\mathrm{PaO}_{2}: \mathrm{FiO}_{2}$ ratio is the worst among those with hyperglycemia compared with diabetic individuals and those with normal blood glucose values [10].

\section{Mortality}

Eight studies reported a higher mortality in patients with hyperglycemia compared with those with normal blood glucose levels. Random effects model was used to compute pooled odds ratio for the same. SARS-CoV-2 infected patients who presented with raised blood glucose levels had an approximately threefold increased risk of dying when compared with those with normal glucose levels at presentation (pooled OR 2.822, 95\% CI 1.587-5.019, $P<0.001$ ) (Fig. 1b).

\section{Discussion}

Our pooled analysis showed an increased risk of critical illness or severe COVID-19, as well as mortality in patients who presented with raised glucose levels and no prior history of diabetes compared with those with normal glucose levels. Diabetes is a comorbidity that negatively affects prognosis of COVID-19 disease, but the impact of hyperglycemia in those without an established diagnosis of diabetes is a more concerning matter for clinicians. Research has shown that acute hyperglycemia can cause impairment in innate immunity, leading to a heightened risk of infections [19]. There is substantial evidence to suggest that hyperglycemia at admission is associated with worse outcomes in communityacquired pneumonia [20]. Few studies have also reported similar results with SARS and MERS viruses [21,22]. Glucose is pro-inflammatory and causes generation of reactive oxygen species (ROS), leading to acute oxidative and inflammatory stress [23]. This milieu of heightened inflammation can possibly be a contributing factor to the cytokine storm witnessed in COVID patients, resulting in more severe illness. It is wellknown that glycosylation (a consequence of sustained hyperglycemia) of the ACE2 receptor increases the propensity of virus linkage to this cellular receptor [24]. Conceivably, this aberrantly glycosylated ACE2 in the tissue in uncontrolled hyperglycemia not only favors the cellular intrusion of SARS-CoV2 but subsequently leads to a wide-spread organ involvement and a greater disease severity, thus translating
Table 2 Studies reporting adverse clinical outcomes in COVID-19 patients with hyperglycemia

\begin{tabular}{|c|c|}
\hline Author, year & Findings \\
\hline Liu et al. [18] & $\begin{array}{l}\text { Fasting blood glucose at admission (irrespective of diabetic status) was an independent } \\
\text { predictor of ICU admission (OR } 1.587,95 \% \text { CI1.299-1.939, } P<0.001)\end{array}$ \\
\hline $\begin{array}{l}\text { Zhang et al. } \\
\text { [7] }\end{array}$ & $\begin{array}{l}\text { Patients with hyperglycemia were more likely to need mechanical ventilation ( } 38.1 \% \text { vs } 9.5 \%) \text {, } \\
\text { stay in the hospital for a longer duration }(26.2 \pm 14.8 \text { vs } 20.5 \pm 11.3 \text { days })\end{array}$ \\
\hline $\begin{array}{l}\text { Smith et al. } \\
{[15]}\end{array}$ & $\begin{array}{l}\text { Disease severity was defined in terms of the requirement for intubation. The intubation rate in } \\
\text { non-diabetic patients was } 4 \% \text {, while that of pre-diabetics was } 18.5 \%\end{array}$ \\
\hline $\begin{array}{l}\text { Wang et al. } \\
\text { [11] }\end{array}$ & $\begin{array}{l}\text { Among patients without a previous diagnosis of diabetes, admission fasting plasma glucose } \\
\text { (FBG) } \geq 7.0 \mathrm{mmol} / \mathrm{L} \text { and } 6.1-6.9 \mathrm{mmol} / \mathrm{L} \text { were at a higher risk of in-hospital complications } \\
\text { compared with those with } \mathrm{FPB}<6.0 \mathrm{mmol} / \mathrm{L} \text { (OR } 3.99,95 \% \text { CI } 2.71-5.88 \text {; OR } 2.61,95 \% \\
\text { CI } 1.64-4.41 \text {, respectively) }\end{array}$ \\
\hline Li et al. [12] & $\begin{array}{l}\text { Compared with hyperglycemia, normoglycemia in COVID- } 19 \text { was associated with a higher } \\
\text { chance of developing acute respiratory distress syndrome }(0.8 \% \text { vs } 3.1 \%) \text {, acute kidney } \\
\text { injury }(1.5 \% \text { vs } 3.1 \%) \text {, shock }(2.3 \% \text { vs } 4.7 \%) \text {, non-invasive ventilation }(2.3 \% \text { vs } 5.4 \%) \text {, } \\
\text { invasive ventilation }(2.3 \% \text { vs } 4.7 \%) \text {, and admission to ICU }(1.5 \% \text { vs } 6.2 \%)(P<0.05)\end{array}$ \\
\hline $\begin{array}{l}\text { Zhang et al. } \\
{[6]}\end{array}$ & $\begin{array}{l}\text { Risk of acute respiratory distress syndrome ( } 3 \% \text { vs } 2 \%) \text {, acute kidney injury ( } 2 \% \text { vs } 0 \%) \text {, and } \\
\text { septic shock }(8 \% \text { vs } 2 \%) \text { was higher in the impaired fasting glucose group vs normal fasting } \\
\text { glucose }(P<0.05) \text {. }\end{array}$ \\
\hline
\end{tabular}


Studies

Fadini et al.

Li et al.

Liu et al.

Wu et al.

Zhang et al. (1)

Zhang et al. (2)
Odds Ratio (95\% C.I.)

$1.630(1.328,2.000)$

$1.627(0.967,2.737)$

$1.245(1.056,1.468)$

$2.250(1.764,2.870)$

$2.860(1.198,6.830)$

$5.846(1.864,18.334)$

Overall $\left(I^{\wedge} 2=78.31 \%, P<0.001\right) \quad 1.837 \quad(1.368, \quad 2.465)$

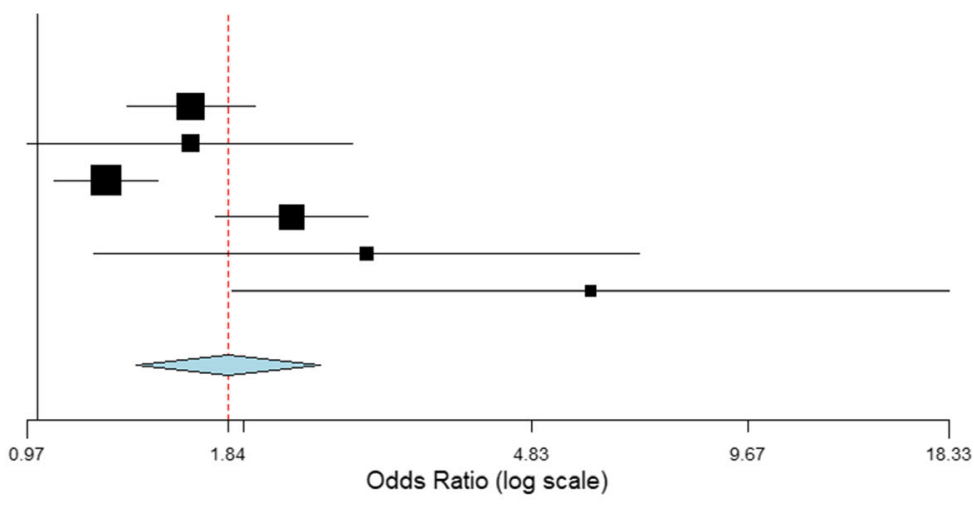

Studies

Bode et al.

Coppelli et al.

Li et al.

Smith et al.

Wang et al.

Wu et al.

Zhang et al. (1)

Zhang et al. (2)

Overall $\left(\left.\right|^{\wedge} 2=73.14 \%, P<0.001\right)$

b
Odds Ratio (95\% C.I.)
$\begin{array}{rrr}10.774 & (6.038, & 19.224) \\ 2.110 & (1.023, & 4.350) \\ 2.640 & (0.498, & 14.000) \\ 0.587 & (0.121, & 2.845) \\ 2.300 & (1.490, & 3.550) \\ 2.880 & (1.556, & 5.330) \\ 4.110 & (1.146, & 14.740) \\ 1.583 & (0.382, & 6.569) \\ 2.822 & (1.587, & 5.019)\end{array}$

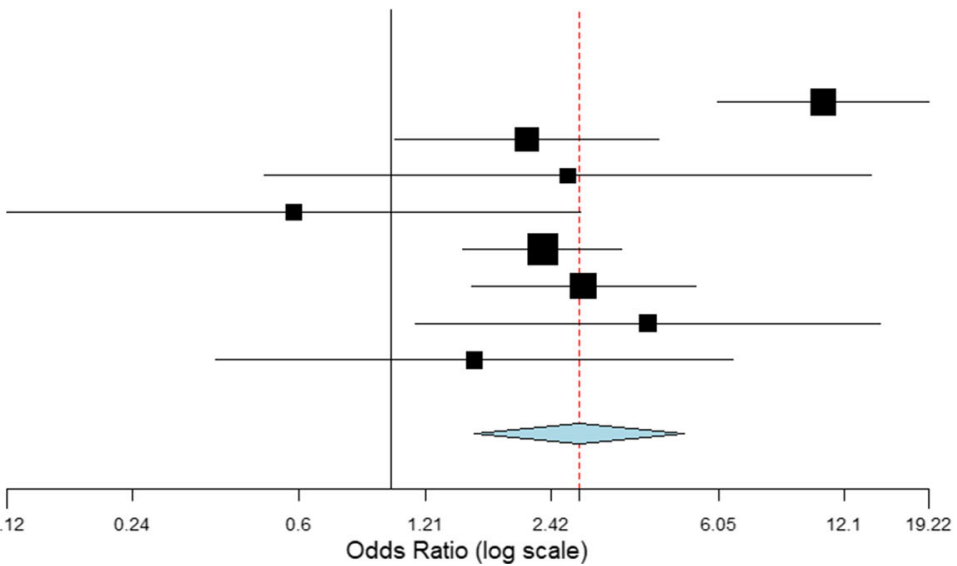

Fig. 1 Pooled OR for a severe/critical COVID-19 illness. b Mortality in COVID-19

into worse outcomes. Worsening respiratory function is believed to be the major factor responsible for the detrimental effect of hyperglycemia in patients infected by SARS-CoV-2 [8]. It has been observed that there exist varying magnitudes of association between fasting blood glucose levels and severe/critical COVID-19 illness among patients presenting with hyperglycemia without a known diagnosis of diabetes. Additionally, the shape of such an association is J-shaped as shown by Zhu et al. in their study [25].

Further, it has been reported that optimal glycemic control of hyperglycemia in COVID-19 patients leads to a reduction in the risk of severe disease and death [17]. Therefore, it is of utmost importance that plasma sugar values be strictly monitored in all COVID-19 patients, more so in the critically- ill patients.

We do acknowledge some limitations to our study. Patients presenting with raised glucose levels (especially glucose levels $>7.0 \mathrm{mmol} / \mathrm{L}$ ) may be cases of new-onset diabetes or may have missed being diagnosed in the past. Criteria for placing patients into the normoglycemia and hyperglycemia groups was not consistent throughout all studies (refer Table 1). Also, comorbidities such as hypertension, cardiovascular disease, chronic kidney, and liver disease were not accounted for in all included studies.

\section{Conclusions}

Hyperglycemia is a significant blood finding in patients admitted in view of COVID-19 and can be used as a prognostic marker to stratify based on risk of severe disease and death, thus enabling early intervention resulting in improved patient outcomes. Glycemic status rather than a prior diagnosis of diabetes is a predictor of adverse outcomes. The need for timely recognition and management of blood glucose levels should be emphasized in COVID-19 disease. Large-scale patient studies are warranted in order to establish appropriate treatment guidelines for hyperglycemia in COVID-19 patients, so as to minimize worse outcomes for these patients.

\section{Compliance with Ethical Standards}

Conflict of Interest The authors declare that they have no conflict of interest.

Ethical Approval This article does not contain any studies with human participants or animals performed by any of the authors.

Informed Consent NA 


\section{References}

1. Li Q, Guan X, Wu P, Wang X, Zhou L, Tong Y, et al. Early transmission dynamics in Wuhan, China, of novel coronavirusinfected pneumonia. N Engl J Med. 2020;382(13):1199-207. https://doi.org/10.1056/NEJMoa2001316.

2. Huang I, Lim MA, Pranata R. Diabetes mellitus is associated with increased mortality and severity of disease in COVID-19 pneumonia - a systematic review, meta-analysis, and meta-regression. Diabetes Metab Syndr. 2020;14(4):395-403. https://doi.org/ 10.1016/j.dsx.2020.04.018.

3. Yang J, Lin S, Ji X, Guo L. Binding of SARS coronavirus to its receptor damages islets and causes acute diabetes. 2020.

4. Lepper PM, Ott S, Nüesch E, et al. Serum glucose levels for predicting death in patients admitted to hospital for community acquired pneumonia: prospective cohort study. BMJ. 2012;344:e 3397. Published 2012 May 28. https://doi.org/10.1136/bmj.e3397.

5. Ceriello A, Zarich SW, Testa R. Lowering glucose to prevent adverse cardiovascular outcomes in a critical care setting. J Am Coll Cardiol. 2009;53(5 Suppl):S9-S13. https://doi.org/10.1016/j.jacc. 2008.09.054.

6. Zhang J, Kong W, Xia P, et al. Impaired Fasting Glucose and Diabetes are related to higher risks of complications and mortality among patients with coronavirus disease 2019. Front Endocrinol (Lausanne). 2020;11:525. Published 2020 Jul 10. https://doi.org/ 10.3389/fendo.2020.00525

7. Zhang Y, Li H, Zhang J, Cao Y, Zhao X, Yu N, et al. The clinical characteristics and outcomes of patients with diabetes and secondary hyperglycaemia with coronavirus disease 2019: a single-centre, retrospective, observational study in Wuhan. Diabetes Obes Metab. 2020;22(8):1443-54. https://doi.org/10.1111/dom.14086.

8. Fadini GP, Morieri ML, Boscari F, Fioretto P, Maran A, Busetto L, et al. Newly-diagnosed diabetes and admission hyperglycemia predict COVID-19 severity by aggravating respiratory deterioration [published online ahead of print, 2020 Aug 15]. Diabetes Res Clin Pract. 2020;168:108374. https://doi.org/10.1016/j.diabres. 2020.108374.

9. Liu Q, Chen H, Li J, Huang X, Lai L, Li S, et al. Fasting blood glucose predicts the occurrence of critical illness in COVID-19 patients: a multicenter retrospective cohort study. J Inf Secur. 2020;81(3):e20-3. https://doi.org/10.1016/j.jinf.2020.07.006.

10. Coppelli A, Giannarelli R, Aragona M, et al. Hyperglycemia at hospital admission is associated with severity of the prognosis in patients hospitalized for COVID-19: the Pisa COVID-19 study [published online ahead of print, 2020 Aug 11]. Diabetes Care. 2020;dc201380. https://doi.org/10.2337/dc20-1380

11. Wang S, Ma P, Zhang S, Song S, Wang Z, Ma Y, et al. Fasting blood glucose at admission is an independent predictor for 28-day mortality in patients with COVID-19 without previous diagnosis of diabetes: a multi-centre retrospective study. Diabetologia. 2020;63(10):2102-11. https://doi.org/10.1007/s00125-020-052091.

12. Li H, Tian S, Chen T, et al. Newly diagnosed diabetes is associated with a higher risk of mortality than known diabetes in hospitalized patients with COVID-19 [published online ahead of print, 2020 May 29]. Diabetes Obes Metab. 2020;https://doi.org/10.1111/ dom. 14099.

13. Wu J, Huang J, Zhu G, Wang Q, Lv Q, Huang Y, et al. Elevation of blood glucose level predicts worse outcomes in hospitalized patients with COVID-19: a retrospective cohort study. BMJ Open
Diabetes Res Care. 2020;8(1):e001476. https://doi.org/10.1136/ bmjdrc-2020-001476.

14. Bode B, Garrett V, Messler J, McFarland R, Crowe J, Booth R, et al. Glycemic characteristics and clinical outcomes of COVID-19 patients hospitalized in the United States [published correction appears in J Diabetes Sci Technol. 2020 Jun 10;:1932296820932678]. J Diabetes Sci Technol. 2020;14(4):813-21. https://doi.org/10. $1177 / 1932296820924469$.

15. Smith SM, Boppana A, Traupman JA, et al. Impaired glucose metabolism in patients with diabetes, prediabetes, and obesity is associated with severe COVID-19 [published online ahead of print, 2020 Jun 26]. J Med Virol. 2020;https://doi.org/10.1002/jmv. 26227.

16. Iacobellis G, Penaherrera CA, Bermudez LE, Bernal ME. Admission hyperglycemia and radiological findings of SARSCoV2 in patients with and without diabetes. Diabetes Res Clin Pract. 2020;164:108185. https://doi.org/10.1016/j.diabres.2020. 108185.

17. Sardu C, D'Onofrio N, Balestrieri ML, et al. Outcomes in patients with hyperglycemia affected by COVID-19: can we do more on glycemic control? Diabetes Care. 2020;43(7):1408-15. https://doi. org/10.2337/dc20-0723.

18. Liu SP, Zhang Q, Wang W, Zhang M, Liu C, Xiao X, et al. Hyperglycemia is a strong predictor of poor prognosis in COVID19 [published online ahead of print, 2020 Jul 24]. Diabetes Res Clin Pract. 2020;167:108338. https://doi.org/10.1016/j.diabres.2020. 108338.

19. Jafar N, Edriss H, Nugent K. The effect of short-term hyperglycemia on the innate immune system. Am J Med Sci. 2016;351(2): 201-11. https://doi.org/10.1016/j.amjms.2015.11.011.

20. McAlister FA, Majumdar SR, Blitz S, Rowe BH, Romney J, Marrie TJ. The relation between hyperglycemia and outcomes in 2,471 patients admitted to the hospital with community-acquired pneumonia. Diabetes Care. 2005;28(4):810-5. https://doi.org/10.2337/ diacare.28.4.810.

21. Yang JK, Feng Y, Yuan MY, Yuan SY, Fu HJ, Wu BY, et al. Plasma glucose levels and diabetes are independent predictors for mortality and morbidity in patients with SARS. Diabet Med. 2006;23(6):623-8. https://doi.org/10.1111/j.1464-5491.2006. 01861.x.

22. Alanazi KH, Abedi GR, Midgley CM, Alkhamis A, Alsaqer T, Almoaddi A, et al. Diabetes mellitus, hypertension, and death among 32 patients with MERS-CoV infection, Saudi Arabia. Emerg Infect Dis. 2020;26(1):166-8. https://doi.org/10.3201/ eid2601.190952.

23. Mohanty P, Hamouda W, Garg R, Aljada A, Ghanim H, Dandona P. Glucose challenge stimulates reactive oxygen species (ROS) generation by leucocytes. J Clin Endocrinol Metab. 2000;85(8): 2970-3. https://doi.org/10.1210/jcem.85.8.6854.

24. Brufsky A. Hyperglycemia, hydroxychloroquine, and the COVID19 pandemic. J Med Virol. 2020;92(7):770-5. https://doi.org/10. 1002/jmv.25887.

25. Zhu B, Jin S, Wu L, Hu C., Wang Z., Bu L., Sun H., Wang X., Qu S., Chen D. J-shaped association between fasting blood glucose levels and COVID-19 severity in patients without diabetes [published online ahead of print, 2020 Aug 25]. Diabetes Res Clin Pract 2020;168:108381. doi:https://doi.org/10.1016/j.diabres.2020. 108381.

Publisher's Note Springer Nature remains neutral with regard to jurisdictional claims in published maps and institutional affiliations. 